
\title{
$\angle S$ Research Square \\ Distribution of organic carbon and nutrients in soil aggregates under different Cunninghamia lanceolata stand types in southern Guangxi of China
}

\author{
Yongzhen Huang \\ Guangxi University \\ Shengqiang Wang \\ Guangxi University
}

Shaoming Ye (D wsq_sicau@163.com )

Guangxi University

Research

Keywords: Fir plantation, Soil aggregates, Organic carbon, Nutrients

Posted Date: February 25th, 2021

DOI: https://doi.org/10.21203/rs.3.rs-238496/v1

License: @ (i) This work is licensed under a Creative Commons Attribution 4.0 International License. Read Full License 


\section{Abstract}

Background: By microscopically characterizing soil organic carbon $\left(\mathrm{C}_{\text {org }}\right)$ and nutrients pertaining to different Cunninghamia lanceolata stands at aggregate scale. A theoretical foundation can be laid to more sustainably employ soil resources in Cunninghamia lanceolata plantations, thus improving soil health and fertility.

Methods: Soil $\mathrm{C}_{\text {org }}$, total nitrogen $\left(\mathrm{N}_{\text {tot }}\right)$, available phosphorus $\left(\mathrm{P}_{\text {ava }}\right)$ and exchangeable cations (including calcium $\left(\mathrm{Ca}^{2+}\right)$, magnesium $\left(\mathrm{Mg}^{2+}\right)$, potassium $\left(\mathrm{K}^{+}\right)$and sodium $\left(\mathrm{Na}^{+}\right)$) received the analysis within aggregate fractions acquired from 0-10 cm and 10-20 cm depth in three different stands, mixed stand of Cunninghamia lanceolata and Michelia macclurei (stand A), Cunninghamia lanceolata and Mytilaria laosensis (stand B) and pure stand of Cunninghamia lanceolata (stand C), respectively. The soil aggregates were classified into macroaggregates $(>2 \mathrm{~mm})$, meso-aggregates $(2-0.25 \mathrm{~mm})$ and micro-aggregates $(<0.25 \mathrm{~mm})$ fractions by one drysieving process.

Results: The two mixed stands displayed a relationship with the higher stable characteristic pertaining to soil aggregates than the pure stand, especially stand A. Meanwhile, micro-aggregates acted as the main fractions that carried soil $\mathrm{C}_{\text {org }}, \mathrm{N}_{\text {tot }}$, and $\mathrm{P}_{\text {ava }}$, and both micro- and macro-aggregates referred to the main fractions that carried exchangeable cations. As for the soil nutrient stocks, only the exchangeable $\mathrm{K}^{+}$cation stock of the pure stand dominated among the $\mathrm{C}_{\text {org }}$ and nutrients stocks, in addition, the rest of the other nutrients stocks of the mixed forests (stand $\mathrm{A}$ and $\mathrm{B}$ ) took an advantage over the pure stand. Moreover, the $\mathrm{C}_{\text {org }}$ and nutrients stocks in stand $A$ and $B$ were reflected in the macro-aggregates, differently, those of stand $C$ were mainly reflected in the micro-aggregates.

Conclusions: Thus, selecting suitable broadleaf tree species mixed with Cunninghamia lanceolata can alleviate the problems of pure stand soil aggregate stability reduction and soil $\mathrm{C}_{\text {org }}$ and nutrient loss for promoting soil resources to be sustainably utilized and protecting the health and quality of soil in the hilly area in southern Guangxi, China.

\section{Background}

As the basic unit of soil structure, aggregate can coordinate the water, fertilizer, air and heat in the soil, it is the material basis for the formation of good soil structure and influences the dynamic changes of soil quality and health (Six et al., 2012). Aggregates of different sizes not only determine soil physically related and chemically characteristics such as soil morphology, distribution and quantity of pores, but also critically impact the supply, conservation and transformation of soil nutrients (Six et al., 2012; Egan et al., 2018). And its stability is influenced by a number of factors, including soil organic carbon $\left(\mathrm{C}_{\text {org }}\right)$ and nutrient contents, surface runoff, etc (Almajmale et al., 2017). In general, primary particles receive the binding process via persistent binders (humic organics and multivalent metal cation complexes), aluminosilicates disordered significantly, and oxide for forming micro-aggregates (Voltolini et al., 2017). Then, one micro-aggregate aggregation by using shortlived and temporary organic binders can created macro-aggregates; the mentioned binders receive the major covering within fungal hyphae, polysaccharides, and plant roots of microbial and plant origin (Li et al., 2019). Macro-aggregates with a stable structure can store more organic matter and nutrients, reducing rainwater erosion, surface runoff, achieving water and fertilizer retention (Zhao et al., 2017). And physical disturbance 
will cause macro-aggregates stability to be reduced, relative steady micro-aggregates will receive the creation, underpinning the -aggregates form cycle below (Ma et al., 2015). Therefore, it is important to study the different aggregate sizes because they can significantly maintain soil $\mathrm{C}_{\text {org }}$ and nutrients.

For insights into mechanism to sequester soil organic matter, we need to quantify their location in different aggregate sizes, because the distribution of soil aggregate-related $\mathrm{C}_{\text {org }}$ and nutrients will impact organic matters microbial degrading process (Geb et al., 2019). There are various studies about soil aggregate-relevant $\mathrm{C}_{\text {org }}$ and nutrients distribution patterns recently. For example, Soil $\mathrm{C}_{\text {org }}$, total nitrogen $\left(\mathrm{N}_{\text {tot }}\right)$ and available phosphorus $\left(\mathrm{P}_{\mathrm{ava}}\right)$ contents declined noticeably with the increase of aggregate sizes (Wu et al., 2018; Zou et al., 2018), while in other studies, the opposite trends were achieved (Ranatunga et al., 2013; Egan et al., 2018). Obviously, the soil aggregate-relevant $\mathrm{C}_{\text {org }}, \mathrm{N}_{\text {tot }}$ and $\mathrm{P}_{\text {ava }}$ were widely reported, yet the exchangeable cations (namely, magnesium $\left(\mathrm{Mg}^{2+}\right)$, calcium $\left(\mathrm{Ca}^{2+}\right)$, sodium $\left(\mathrm{Na}^{+}\right)$and potassium $\left(\mathrm{k}^{+}\right)$) are rarely explored. The chemically-related aggregating process driving elements (e.g., $\mathrm{Mg}^{2+}$ and $\mathrm{Ca}^{2+}$ ), forming cationic bridges containing soil $\mathrm{C}_{\text {org }}$, can then be conducive to protecting organic matters from being decomposed (Jiang et al., 2011).The distribution of cations is capable of impacting aggregating process and microbial degrading process for soil organic matter, and accordingly the way to quantify their location in aggregate sizes can present insights into the systems to sequester soil organic matter (Jiang et al., 2011).

The area of plantation forests in China is about 79.0 million hectare, accounting for about $36.0 \%$ of the national forest area and $48.5 \%$ of the world's total (Ke et al., 2020), which ranks first in the world.

Cunninghamia lanceolata with the characteristics of fast growing, good quality and high process ability and high economic value, it is an important forestation species in China. Approximately $19.0 \%$ of the country's plantation forests area is planted with Cunninghamia lanceolata (Zhu et al., 2020). Because of the unique geographical location and climate, Guangxi has become a major forestry province. However, low productivity of planted forests has been a major problem in China's planted forests for a long time. The per-hectare forest stocking of China is only $95 \mathrm{~m}^{3} / \mathrm{ha}$, much lower than the international average $\left(131 \mathrm{~m}^{3} / \mathrm{ha}\right)$, and the perhectare forest stocking of Guangxi is only $64.5 \mathrm{~m}^{3} /$ ha (Macdicken et al., 2015; Ke et al., 2020). The multigenerational replanting of pure forests in pursuit of timber productivity, which has serious implications for the sustainable management of planted forests. It leads to homogeneous stand structure, poor ecological stability and declining soil fertility.

However, the second-generation Cunninghamia lanceolata plantation caused soil fertility and productive capability to be severely reduced (Guan et al., 2015). General measures related to acquiring and regenerating employed on Cunninghamia lanceolata plantations are clear-cutting and controlled burning, the measures cause soil organic matter and nutrients to be severely lost simultaneously (Liao, 2015). For solving the issue, mixed forest managing process is considered a vital orientation to sustainably manage plantations. For example, degraded Cunninghamia lanceolata plantations are gradually rebuilt through intercropping with Michelia macclurei, and reestablished the autotrophic mechanisms of the forest (Wang et al., 2000), increasing the productivity of forest stands. Soil is strongly influenced by vegetation factors (Feng et al., 2020). And the distributing characteristics pertaining to soil aggregates and aggregate stable property lead to variations within microbial behaviors and soil nutrient circulating process, more specifically affecting soil biogeochemical reacting processes. The better soil aggregate structure can noticeably help soil $\mathrm{C}_{\text {org }}$ be 
balanced and stable (Wang et al., 2020a). Therefore, the present study aimed at determining the influences exerted by different stand types on the contents and stocks of $\mathrm{C}_{\text {org }}$ and nutrients within various soil aggregates. It is hypothesized that (i) the micro-aggregates are the major elements carrying soil $\mathrm{C}_{\text {org }}$ and nutrients since the carbon sequestration of micro-aggregates is the result of the tight combination of organic and inorganic colloids, and micro-aggregates exhibiting wider specific surfaces are able to offer appropriate sites for $\mathrm{P}_{\text {ava }}$ and exchangeable cations at the same time. (ii) the $\mathrm{C}_{\text {org }}$ and nutrients stocks of mixed forests are higher than those of pure forests, due to the fact that the mixed plantations exhibit litter decomposition and litter surface covering protection as their advantages.

\section{Materials And Methods}

\section{Experimental site}

This work performed in June 2019 at the experiment center of tropical forestry (Chinese academy of forestry) in Pingxiang, Guangxi, China (Coordinate: $106^{\circ} 41^{\prime}-106^{\circ} 59^{\prime} \mathrm{E}, 21^{\circ} 57^{\prime}-22^{\circ} 16^{\prime} \mathrm{N}$ ) (Figure 1). Subtropical monsoon refers to the common climate at the annual sunshine is about 1220-1600 h, an annual average temperature between $19.5-21.5^{\circ} \mathrm{C}$, an annual rainfall is about $1200-1550 \mathrm{~mm}$ with an relative humidity above $80 \%$. Low mountains and hills are the mainly landform in this area, with an average gradient about $25 \sim 30$ degrees. The native rock is mainly limestone gravel, argillaceous sandstone, granite and limestone. The soil is mainly latosol and krasnozem with a loose texture and the soil layer thickness is over $80 \mathrm{~cm}$. The soil belongs to acid soil with $\mathrm{pH}$ of $4.8 \sim 5.5$, and the acidity increases from the surface to the bottom. The unique soil hydrological conditions in this region provide favorable natural conditions for local agriculture and forestry. The primary vegetation is mainly monsoon forest and rainforest. Nevertheless, as impacted by long-term human interference activities, utilization and logging, the primary monsoon forest vegetation can hardly be found. The secondary forest vegetation is only residual and replaced by a large number of man-made forest.

\section{Design of the experiment}

In this study, forest mixing Cunninghamia lanceolata and Michelia macclurei (stand A), Cunninghamia lanceolata and Mytilaria laosensis (stand B), pure forest of Cunninghamia lanceolata (stand C) in Qingshan experimental site were selected according to the geological conditions and site conditions. The three stand types were constructed in 1992, with a row spacing of $2 \mathrm{~m} \times 3 \mathrm{~m}$, and a 3:1 mixed proportion of Cunninghamia lanceola with Michelia macclurei and Cunninghamia lanceolata with Mytilaria laosensis. The experiment site with a crown density about 0.85 , has a slope around $27 \sim 35$ degrees, and an altitude of $725 \sim 730 \mathrm{~m}$.

For studying the influence exerted by Cunninghamia lanceolata stand types on the soil $\mathrm{C}_{\text {org }}$ and nutrients in aggregate fractions, five plots with an area of $900 \mathrm{~m}^{2}$ were set in each stand type. Thus, there were 15 plots for organization according to one completely randomized design, exhibiting the distance of $>300 \mathrm{~m}$ of the respective plot for minimizing space-relatedl autocorrelating process. Area of the respective plot was $30 \mathrm{~m} \times$ $30 \mathrm{~m}, 5$ sub-plots were set up according to the "s" shape in each plot. 


\section{Soil and litter sampling}

According to the respective plot, 5 litter samples received the collection from soil surface to the plastic bags by using the 5 randomized sub-plots with an area of $1 \mathrm{~m}^{2}(1 \mathrm{~m} \times 1 \mathrm{~m})$. Subsequently, 5 litter samples received the composition process to one. The 15 composite litter samples all received the oven-drying process at $80^{\circ} \mathrm{C}$ until a constant weight was achieved. Finally, the dried composited litter samples received the weighing process separately; the litter weight in stand A, stand B and stand $C$ were $723.66 \mathrm{~g} \mathrm{~m}^{-2}, 566.84 \mathrm{~g} \mathrm{~m}^{-2}$ and $340.58 \mathrm{~g} \mathrm{~m}^{-2}$ respectly.

Soil samples received the collection in the position the same as that of the collection of litter sample. According to the respective plot, 5 soil samples were collected from $0-10 \mathrm{~cm}$ and $10-20 \mathrm{~cm}$ layer separately, recognized to be rhizosphere soil. Next, they received the incorporation to be the composite one. The 30 composite soil samples collectively received the fragmenting process to nature aggregates rigorously. Then, the samples were sifted via a sieve (mesh size of $5 \mathrm{~mm}$ ) to remove large roots, stones and macro-fauna. In the meantime, 5 soil samples within the respective plot received the random collection with the use of the cutting ring approach $\left(\mathrm{V}=100^{-3}\right)$ for measuring the properties of whole soil, such as bulk density, as well as the contents of $\mathrm{C}_{\text {org }}$ and nutrients (Table 1 ).

\section{Soil aggregate separating process}

Based on the dry-sieving process shown by Yang et al. (2007), the soil aggregates received the isolation. In this process, the air-dried soil sample $(<5 \mathrm{~mm})$ was filtered using sieves with the successive diameter of 0.25 and 2 $\mathrm{mm}$. Next, $20 \mathrm{~min}$ vertical oscillation (along $5 \mathrm{~cm}$ amplitude) was achieved at the 1 oscillation $\mathrm{s}^{-1}$ rate. Then, 3 aggregates were acquired, they were macro-aggregates $(>2 \mathrm{~mm})$, meso-aggregates $(2-0.25 \mathrm{~mm})$, as well as micro-aggregates $(<0.25 \mathrm{~mm}$ ) According to all the fractions exhibited by the aggregates, the contents of soil $\mathrm{C}_{\text {org }}$ and nutrients received the assessment.

\section{Soil property analyses}

Soil samples received the oven-drying process at $105^{\circ} \mathrm{C}$ to the constant weight for measuring the bulk density (Lu, 2000). In addition, soil samples (soil aggregates and the bulk soil) received the 1-week air-drying process under the indoor temperature before soil chemical characteristics are analyzed. Soil $\mathrm{C}_{\text {org }}$ received the measurement by employing acid dichromate wet oxidization (Nelson and Sommers, 1996). Based on the micro-Kjeldahl approach (Bremner, 1996) $\mathrm{N}_{\text {tot }}$ received the measuring process. $\mathrm{P}_{\text {ava }}$ received the measuring process based on molybdenum blue colorimetric procedure (Bray and Kurtz, 1945). Based on ammonium acetate replacement method, exchangeable cations received the measurement (Thomas, 1982).

\section{Calculations and statistical analyses}

The stable property exhibited by soil aggregates received the estimation, as determined by adopting the equation of Nimmo and Perkins, 2002: 
MWD $=\sum_{i=1}^{3}(X i \times W i)$

where $W i$ is the aggregate proportion at $\mathrm{i}^{\text {th }}$ size within the bulk soil(\%); $X i$ is the aggregate average diameter in $i^{\text {th }}(\mathrm{mm})$ size.

Based on the method established by Eynard et al. (2005), $\mathrm{C}_{\text {org }}$ stock (CS, $\left.\mathrm{g} \mathrm{m}^{-2}\right)$ in the bulk soil is:

$$
\mathrm{CS}=\sum_{i=1}^{3}(\operatorname{Corg} i \times W i) \times B d \times H \times 10
$$

where Corg $i$ expresses the content of $\mathrm{C}_{\text {org }}$ in aggregates at $\mathrm{i}^{\text {th }}\left(\mathrm{g} \mathrm{kg}^{-1}\right)$ size; $\mathrm{W}_{\mathrm{i}}$ is the aggregate proportion at $\mathrm{i}^{\text {th }}$ size in the bulk soil (\%); $B d$ is the bulk density in the bulk soil $\left(\mathrm{g} \mathrm{cm}^{-3}\right) ; H$ is the soil thickness (cm). Likewise, we determined nutrient stocks in the bulk soil.

Based on SAS university edition software, we carried out the statistics-relevant investigations. Outcomes have the expression of the average of 5 replicates. We made the one-way variance study for assessing how stand type influenced soil features. Furthermore, based on a generalized linear model, we performed the variance investigation the split-plot for determining the effect and interacting process pertaining to aggregate size and stand type.

\section{Results}

Bulk soil properties

The litter quantity in the stand A and stand B was remarkably higher than those in stand C. While in Table 1, soil $C_{\text {org }}$ and nutrients were decrease with the deepening of soil layer while the ratio $\left(R_{d m}\right)$ of divalent cation (exchangeable $\mathrm{Ca}^{2+}$ and $\mathrm{Mg}^{2+}$ ) to monovalent cation (exchangeable $\mathrm{K}^{+}$and $\mathrm{Na}^{+}$) and bulk density were opposite. The contents of soil $\mathrm{C}_{\text {org }}, \mathrm{N}_{\text {tot }}, \mathrm{P}_{\text {ava }}$, monovalent cation, soil bulk density and the $\mathrm{R}_{\mathrm{dm}}$ were significantly different, while significant differences in soil $\mathrm{C} / \mathrm{N}$ ratio, total exchangeable bases(total EB), divalent cation were not found among the three stands in the $0-10 \mathrm{~cm}$ soil layer. Besides, soil $\mathrm{C}_{\text {org }}$ and nutrients were significantly different among the three stands in 10-20 cm soil layer. Among the three stands, stand $A$ and $B$ had obvious advantage over stand $C$ in 0-10 cm layer. Nevertheless, there was no obvious regular change in 10-20 $\mathrm{cm}$ layer.

Soil aggregate distribution and stability

In the three stands, macro-aggregates took up the main parts in the bulk soil, with the average proportion of $43.1 \%, 37.3 \%$ in $0-10 \mathrm{~cm}$ and $10-20 \mathrm{~cm}$ soil layer respectively. Among the other two aggregates, the proportion of meso-aggregates was significantly higher than that of micro-aggregates in $0-10 \mathrm{~cm}$ soil layer, but it was opposite in the $10-20 \mathrm{~cm}$ soil layer(Table 2). Soil aggregates of various sizes were significantly impacted by 
the type of stands, except for meso-aggregates in 0-10 cm layer. Specifically, macro-aggregates in stand A were remarkably higher than that in stand $B$ and stand $C$, but an inverse trend was identified for microaggregates. However, there was no significant change in meso-aggregates. Besides, the MWD showed a significant difference between each stand, which were ranking as stand $\mathrm{A}>\operatorname{stand} \mathrm{B}>\operatorname{stand} \mathrm{C}$.

Soil aggregate-relevant $\mathrm{C}_{\text {org }}, \mathrm{N}_{\text {tot }}$ and $\mathrm{P}_{\text {ava }}$ contents

Soil aggregate-relevant $\mathrm{C}_{\text {org }}, \mathrm{N}_{\text {tot }}$ and $\mathrm{P}_{\text {ava }}$ contents exhibited an obvious variation depending on the interaction of stand type and aggregate size in 0-10 cm soil layer, and the effect of stand type on soil aggregate in 10-20 cm soil layer were more significant (Table 3). In Figure 2, $\mathrm{C}_{\text {org }}$ and nutrients were decreased with the deepening of soil layer. Regardless of the different stand types, the contents of soil $\mathrm{C}_{\text {org }}$ were significantly increased as the size of aggregates decreased. And the contents of soil $\mathrm{P}_{\text {ava }}$ in the mesoaggregates and micro-aggregates were significantly higher than those in macro-aggregates in 0-10 cm soil layer, while the contents of $N_{\text {tot }}$ and the aggregate-relevant $C / N$ ratio in both soil layers and $P_{\text {ava }}$ in $10-20 \mathrm{~cm}$ soil layer were evenly distributed in the aggregate of various sizes. Moreover, the contents of soil $\mathrm{C}_{\text {org }}$ in stand A were remarkably higher than that in stand $B$ and $C$ in both layer, while the contents of soil $N_{\text {tot }}$ and $P_{\text {ava }}$ of stand $A$ and $B$ in $0-10 \mathrm{~cm}$ soil layer were significantly greater than that in stand $C$. And the lowest content of $P_{\text {ava }}$ occurred in stand $B$ in 10-20 cm layer. Besides, there was a significant difference between stand $A$ and $C$ when comes to the $\mathrm{C} / \mathrm{N}$ ratio in $10-20 \mathrm{~cm}$ layer.

Soil aggregate-relevant exchangeable cation contents

Soil aggregate-relevant exchangeable cation contents exhibited an obvious variation depending on the stand type in 10-20 cm soil layer, while the influence of stand type and aggregate size on monovalent cation was significant, and both stand type and aggregate size had no significant influence on divalent cation in 0-10 cm soil layer (Table 3). Soil total EB and various exchangeable cations (that is $\mathrm{K}^{+}, \mathrm{Na}^{+}, \mathrm{Ca}^{2+}$ and $\mathrm{Mg}^{2+}$ ) were decreased with the deepening of soil layer. Among them, $\mathrm{K}^{+}$and $\mathrm{Mg}^{2+}$ contents were mainly concentrated on micro-aggregates. $\mathrm{Na}^{+}$content was mainly focus on macro-aggregates in $0-10 \mathrm{~cm}$ layer but it was opposite in 10-20 cm layer. There were no significant difference between different aggregate sizes of total $\mathrm{EB}$ and $\mathrm{Ca}^{2+}$ content. Meanwhile, the contents of those exchangeable cation fallowed the order of $\mathrm{Ca}^{2+}>\mathrm{Mg}^{2+}>\mathrm{K}^{+}$and $\mathrm{Na}^{+}$ (Figure 3). The content of $\mathrm{Mg}^{2+}$ in 0-10 cm soil layer, total EB, $\mathrm{Na}^{+}, \mathrm{Ca}^{2+}$ in $10-20 \mathrm{~cm}$ layer and $\mathrm{K}^{+}$in both layers in stand $C$ showed an advantage over the stand $B$, and the content of $\mathrm{Na}^{+}$in $0-10 \mathrm{~cm}$ and $\mathrm{Mg}^{2+}$ in $10-20 \mathrm{~cm}$ layer in stand $A$ were dominant. Besides, the lowest $R_{d m}$ appeared in micro-aggregates among the three aggregate sizes which appeared in stand $\mathrm{C}$ among the three stands.

Soil aggregate-relevant $\mathrm{C}_{\text {org }}$ and nutrient stocks

Soil aggregate-relevant $\mathrm{C}_{\text {org }}$ and nutrient stocks exhibited an obvious variation depending on the aggregate size and stand type, especially the aggregate size (Table 4). Soil $\mathrm{C}_{\text {org }}$ and nutrients stocks of macro and mesoaggregates in stand $A$ and $B$ were significantly greater than those in micro-aggregates, but it was opposite in stand C (Figure 4). For instance, soil $C_{\text {org }}$ stocks of macro-aggregates in stand A, B and C were $918.26 \mathrm{~g} \mathrm{~m}^{-2}$, $717.98 \mathrm{~g} \mathrm{~m}^{-2}$ and $347.07 \mathrm{~g} \mathrm{~m}^{-2}$, contributing to $17.50 \%, 36.20 \%$ and $46.30 \%$ of $\mathrm{C}_{\text {org }}$ stock in the bulk soil 
respectively. And the $\mathrm{N}_{\text {tot }}, \mathrm{P}_{\text {ava }}$ and exchangeable cations displayed the same results. Moreover, the stock of $\mathrm{C}_{\text {org}}, \mathrm{N}_{\text {tot }}, \mathrm{P}_{\text {ava }}$, exchangeable $\mathrm{Na}^{+}$in $0-10 \mathrm{~cm}$ soil layer and exchangeable $\mathrm{Mg}^{2+}$ in $10-20 \mathrm{~cm}$ soil layer of stand A showed an advantage over the other stands, and the stock of exchangeable $\mathrm{Mg}^{2+}$ in $0-10 \mathrm{~cm}$ soil layer, $\mathrm{Na}^{+}$ and $\mathrm{Ca}^{2+}$ in 10-20 cm soil layer of stand $\mathrm{A}$ and $\mathrm{C}$ were dominant. Besides, the stock of exchangeable $\mathrm{K}^{+}$of stand $C$ showed significant difference over the other stands in the both soil layers.

\section{Discussion}

Soil aggregate distribution and stability

The distribution of soil aggregates influence the material circulation at aggregate-scale, and determine the soil pore-size proportion (Ferro et al., 2012). Stable aggregates can reduce soil erosion and surface runoff, protect soil $\mathrm{C}_{\text {org }}$ and improve soil fertility (Wiesmeier et al., 2012; Fattet et al., 2011). Thus, it is necessary to analyze the distribution and stability of soil aggregates to evaluate the soil structure. In this study, stand A and stand B (in 0-10 cm layer) benefited the formation of macro-aggregates, while stand B (in 10-20 cm layer) and stand $C$ produced a significant increase in micro-aggregates, no evident differences were found in meso-aggregates between the three stands. These results confirmed that the distribution of soil aggregates was effected by the stand types (Cheng et al., 2018; Wang et al., 2019).

The differences in soil aggregates stability among different stand types were variations in MWD among the three stands. The decline of MWD was caused by variations in soil aggregate distributing process, in particular for macro-aggregates were decomposed into micro-aggregates (Wang et al., 2020a), explaining that the soil stability of stand $A$ was greater than the other stand types, and stand $C$ had the most unstable soil structure. Meanwhile, the stability of soil aggregate in upper soil layer was higher than that in lower layer. As we all known that soil $\mathrm{C}_{\text {org }}$ was one of the most important aggregate binders, and the content of $\mathrm{C}_{\text {org }}$ was highly correlated with soil aggregate stability (Egan et al., 2018). The content of $C_{\text {org }}$ in stand $A$ and $B$ was significantly higher than that in stand $\mathrm{C}$, and decreased with the deepening of soil layer due to the reduction of soil macro-aggregates, it is also explained from another aspect that the soil structure stability of the mixed forests are better than that of pure forest. Besides, the quality of plant residues could determine the distribution patterns in soil aggregate of different sizes in the hierarchy concept of soil aggregates (Six et al., 2004), which resulting in influencing soil aggregates dynamics. Compared to the pure Cunninghamia lanceolata stand, the mixed forests (Cunninghamia lanceolata and Michelia macclurei, Mytilaria laosensis) promoted litter decomposition (Wang et al., 2008; Niu et al., 2009). Because mixed forest litter changed the composition of the microbial community and the lignocellulose-degradation gene complement, accelerated the decomposition of lignocelluloses, while the lignocellulose is the main component of forest litter (Wang et al., 2020b). The litter weight in stand $A$, stand $B$ and stand $C$ were $723.66 \mathrm{~g} \mathrm{~m}^{-2}, 566.84 \mathrm{~g} \mathrm{~m}^{-2}$ and $340.58 \mathrm{~g} \mathrm{~m}^{-2}$ respectly, which were ranking as stand $A>$ stand $B>$ stand $C$, and it was highly consistent with the $C_{\text {org }}$ content of different stand types, because the litters were easy to be integrated to macro-aggregates during decomposition, which was helpful to the formation of macro-aggregate (Tisdall and Oades, 2012). At the same time, soil surface covered with more litter reduce the erosion by rainwater and fragmentation of soil macro-aggregates, which is one of the reasons that the soil aggregate stability of stand A was significant higher than stand B. As a number of researches have presented (Ayoubi et al., 2012; Egan et al., 2018), there 
was a significantly positive correlation $(p<0.05)$ between $C_{\text {org }}$ content and MWD in bulk soil across the three stand types in each soil layer (Figure 5). The peak of soil aggregate stability in 0-10 cm soil layer appeared in stand $A$, which might be due to the $C_{\text {org }}$ content. Besides, the peak of soil aggregate stability in $10-20 \mathrm{~cm}$ soil layer also appeared in stand $A$, it might be the rate $\left(R_{d m}\right)$ of divalent cation to monovalent cation and $C_{\text {org }}$ content both have significant positive effects on it. Potassium and sodium have dispersing effect on aggregates, especially sodium ions; while calcium and magnesium have polymerization effect on aggregates. So the larger the $R_{d m}$ is, the better the formation of macro-aggregates. In this study, the lowest rate $\left(R_{d m}\right)$ in 0 $10 \mathrm{~cm}$ soil layer was found in stand $\mathrm{C}$, which implied that the proportion of monovalent cation (especially the exchangeable $\mathrm{K}^{+}$content) was higher than that in other stand types (Table 1). This might explain the accumulation of micro-aggregates and the lower level of aggregate stability in stand $C$. The rate $\left(R_{d m}\right)$ increased with the depth of soil layer, which due to the accumulation of $\mathrm{K}^{+}$and downward leaching of $\mathrm{Ca}^{2+}$ and $\mathrm{Mg}^{2+}$ in $0-10 \mathrm{~cm}$ layer.

Soil aggregate-relevant $\mathrm{C}_{\text {org }}, \mathrm{N}_{\text {tot }}$, and $\mathrm{P}_{\text {ava }}$ contents

More $\mathrm{C}_{\text {org }}$ and $\mathrm{N}_{\text {tot }}$ contents in soil received the observation in the micro-aggregates in all the stands, because the adsorption capacity of soil aggregates for nutrients was directly proportional to the specific surface area, under the same quality, the smaller the particles size of soil aggregates, the larger the specific surface area. And the turnover time of $\mathrm{C}_{\text {org }}$ in micro-aggregates was longer than that in macro-aggregates (Mangalassery et al., 2013). Thus, the pattern of $C_{\text {org }}$ contents were increased with the decrease of aggregate size was more obvious. Soil $\mathrm{C} / \mathrm{N}$ ratio is an important parameter affecting soil organic matter degradation (Ostrowska and Porebska, 2015). Meanwhile, the soil $\mathrm{C} / \mathrm{N}$ ratio increased with the decrease of aggregate size, indicating that soil organic matters in micro-aggregates were more labile compared to macro-aggregates. Perhaps, the low $\mathrm{C} / \mathrm{N}$ ratio was caused by the greater degradation which was experienced by the macro-aggregate-relevant organic matters. Besides, $\mathrm{P}_{\text {ava }}$ contents were more distributed in meso-aggregates and micro-aggregates in 0$10 \mathrm{~cm}$ soil layer, but distributed in different aggregate fractions evenly in $10-20 \mathrm{~cm}$ layer. However, the contents of $\mathrm{P}_{\mathrm{ava}}$ in the three stands were lower than $7 \mathrm{mg} \cdot \mathrm{kg}^{-1}$, which was a common phenomenon in Southern China. Because the soil in this area is generally acidic and the soil phosphorus content was low, and the long-term weathering leaching and strong sorption of aluminum, iron and calcium made the soil phosphorus availability even lower (Zhang et al., 2019; Lu et al., 2000). With the deepening of soil layer, the $\mathrm{C}_{\text {org }}, \mathrm{N}_{\text {tot }}$ and $\mathrm{P}_{\text {ava }}$ contents of different aggregate sizes decreased, which was consistent with the previous research results.

Among the three stand types, mixed stands (stand A and B) could positively impacted the accumulation of soil $\mathrm{C}_{\text {org }}$ and $\mathrm{N}_{\text {tot }}$ in the aggregate fractions, which was mainly due to the following mechanisms. First, the dead branches and leaves of Cunninghamia lanceolata have the characteristics of remaining in the crown for a period of time before falling off, that is one of the reasons why the litter quality of Cunninghamia lanceolata pure stand was the lowest, and litter residue was one of the sources of soil organic matter (Castellano, et al., 2015). Second, in the mixed forest, the biomass of fine roots of Michelia macclurei and Mytilaria laosensis was larger in the surface soil, and the fine roots of vegetation in the topsoil had a significant positive impact on the decomposition rate of litter leaves (Jiang et al., 2011). Meanwhile, the amount of dead fine roots rapidly decomposed under the action of microorganisms, returning a large amount of nutrients to the soil (Yin et al., 
2014). Third, compared to Cunninghamia lanceolata, Michelia macclurei and Mytilaria laosensis have stronger nitrogen retention capacity (Wang et al., 2008; Niu et al., 2009), which can provide more nitrogen for soil, and the soil microbial activity was stronger in the nitrogen rich space. There was a close association between $\mathrm{C}_{\text {org }}$ and $\mathrm{N}_{\text {tot }}$, and the effects of various environment factors are nearly identical to them. Soil $\mathrm{C} / \mathrm{N}$ ratio did not remarkably change among the different stand types, because it has little relationship with vegetation coverage (Zhou et al., 2018). The accumulation and consumption are relatively fixed due to the fact that they $\left(\mathrm{C}_{\text {org }}\right.$ and $\mathrm{N}_{\text {tot }}$ ) were structural components (Ostrowska and Porebska, 2015). $\mathrm{C} / \mathrm{N}$ ratio of macro-aggregates in stand $\mathrm{A}$, however, significantly different with other two stand types, because $\mathrm{C}_{\text {org }}$ content was the highest in macroaggregates, leading to a higher $\mathrm{C} / \mathrm{N}$ ratio (Fig. 2). The organic matter in mixed stands was higher, because it contains a large number of hydroxyl and carboxyl groups, which can chelate with Fe/Al oxides in soil, reduce the fixation of phosphorus(Wu et al., 2018), and increase the content of $P_{\text {ava }}$ in soil.

Soil aggregates-related exchangeable cation contents

As the research showed that soil exchangeable cation of non-cultivated soil were primarily focused on 4.76-2 and $<0.25 \mathrm{~mm}$ aggregate fractions (Adesodun et al., 2006). There was a generally trend showed that soil exchangeable cation contents showed the decrease in the 4.76-2 $\mathrm{mm}$ aggregate fractions and subsequently rise in the $<0.25 \mathrm{~mm}$ aggregate fractions. As revealed from the mentioned results, the redistributing process of soil exchangeable cation inside aggregates of different sizes could give the credit to the cultivating process. As opposed to the mentioned, the results here exhibited consistent distributing patterns of the mentioned exchangeable cations in soil aggregates based on various stand categories, suggesting that stand type was identical in the distributing structures of the exchangeable cation within soil aggregates. And the exchangeable cation distribution in our study showed a similar result that exchangeable cation contents were the highest in micro-aggregate fractions, which might give the credit to the wider specific surface exhibited by micro-aggregates. And soil aggregates with larger specific surface area increased adsorption of soil exchangeable cation derived from litter residues (Adesodun et al., 2006). The trend with exchangeable cation indicated that the divalent cation $\left(\mathrm{Ca}^{2+}\right.$ and $\left.\mathrm{Mg}^{2+}\right)$ were obviously higher than the monovalent cation $\left(\mathrm{K}^{+}\right.$and $\mathrm{Na}^{+}$), since divalent cation might be held at the exchange complexes in a tighter manner as compared with the monovalent cation (Jiang et al., 2011). The influence exerted by aggregate sizes and stand types on the contents of soil monovalent cation reached over those of divalent cation in 0-10 cm layer, while in $10-20 \mathrm{~cm}$ soil layer, stand types had significantly influence on both monovalent and divalent cation but aggregate sizes only have significant influence on $\mathrm{Na}^{+}$cation, which indicated that the distribution patterns were governed by aggregate sizes and stand types in 0-10 cm soil layer, and mainly affected by stand types in 10-20 cm soil layer.

The total EB of bulk soil plays an important role in buffering soil acidification. Because high total EB represents more $\mathrm{H}^{+}$exchange sites, the more $\mathrm{H}^{+}$exchange sites it has, the ability of soil acid resistance is stronger. In this study, the total EB of the three stand types was similar in 0-10 cm soil layer, while in $10-20 \mathrm{~cm}$ soil layer, the total EB of stand $A$ and $C$ were significantly better than that of stand $B$. That means the ability of soil acid resistance of stand $A$ and stand $C$ was better than stand $B$. Besides, only stand types had significant influence on total EB in 10-20 cm soil layer, which were the same as Wen's et al. (2019) result. Moreover, the average content of exchangeable cation contents in different aggregates sizes showed a pattern that $\mathrm{Ca}^{2+}>$ 
$\mathrm{Mg}^{2+}>\mathrm{K}^{+}>\mathrm{Na}^{+}$, which were the same as Wang's et al. (2020) study, because the exchangeable cation received the easy losing from soil aggregates based on leaching, especially the exchangeable $\mathrm{K}^{+}$and $\mathrm{Na}^{+}$content, and the low exchangeable $\mathrm{K}^{+}$content was mainly due to the excess $\mathrm{K}^{+}$in the soil can be replaced by $\mathrm{Ca}^{2+}$ on the soil colloid in acid soil. There was no significant difference in the distribution of exchangeable $\mathrm{Ca}^{2+} \mathrm{cation}^{2}$ content in different particle sizes, and stand C was significantly better than stand B in $10-20 \mathrm{~cm}$ soil layer while the same result showed in 0-10 $\mathrm{cm}$ of the exchangeable $\mathrm{Mg}^{2+}$ cation, that might because the requirement of divalent cation for the growth of Mytilaria laosensis was higher than that of Cunninghamia lanceolata. However, different from other exchangeable cation contents, the exchangeable $\mathrm{Na}^{+}$content in macro-aggregates was the highest in $0-10 \mathrm{~cm}$ but was the lowest in $10-20 \mathrm{~cm}$ soil layer, which might because the exchangeable $\mathrm{Na}^{+}$cation of macro-aggregates were accumulated in the upper soil layer. And it is interesting that the distribution of exchangeable $\mathrm{Na}^{+}$cation in the same stand type showed an opposite trend in two soil layers between the different aggregates. For example, the content of exchangeable $\mathrm{Na}^{+}$in the same aggregate size was the highest in one soil layer but lowest in another soil layer, which seems like the total content of exchangeable $\mathrm{Na}^{+}$in the same stand type was almost fixed. The monovalent cation contents in stand $\mathrm{C}$ were obviously higher than that of stand $\mathrm{A}$, because the soil exchangeable base of forest has a strong biological cycle effect, that the deep roots of forest can transform the deep non exchangeable base into exchangeable base, so as to improve the contents of exchangeable base in forest, and Cunninghamia lanceolata was the tree species with deep principal roots than other two species. Notably, it was evidently that the soil exchangeable $\mathrm{K}^{+}$content was the highest in pure stand, because the soil exchangeable $\mathrm{K}^{+}$was mainly affected by soil $P_{\text {ava }}$ (Wen et al,. 2019), and negatively correlated with $P_{\text {ava. }}$. Thus, our first hypothesis is supported.

Soil aggregates-relevant $\mathrm{C}_{\text {org }}$ and nutrient stocks

In order to sustainably use soil resources, it is necessary to consider how to maintaining the soil $\mathrm{C}_{\text {org }}$ and nutrients stocks, because it noticeably impacts soil aggregate stable and fertile properties (Sarker et al., 2018). Here, the soil stocks of $C_{\text {org }}$ and nutrients in macro-aggregates had more noticeably contributing effect compared with that in the bulk soil in stand A and B. And micro-aggregates had higher contributing effect on stand $\mathrm{C}$, which means both macro-aggregates and micro-aggregates acted as the primary fractions that carried soil $\mathrm{C}_{\text {org }}$ and nutrients. As the macro-aggregates took up higher ratios inside the bulk soil, they had higher stocks of soil $\mathrm{C}_{\text {org }}$ and nutrients though although macro-aggregates exhibited the lowest contents of $\mathrm{C}_{\text {org }}$ and nutrients. The mentioned results indicated that stand type affected the stocks of $\mathrm{C}_{\text {org }}$ and nutrients in soil aggregates largely based on the alteration of the distributing behaviors pertaining to soil aggregates exhibiting a range of sizes, which was similar to Wang's et al. (2020) result. As for the distribution of $C_{\text {org }}$ and nutrient contents in the different soil layers $(0-10 \mathrm{~cm}$ and $10-20 \mathrm{~cm})$, showing that with the increase of soil depth, the proportion of $\mathrm{C}_{\mathrm{org}}$ and nutrient stocks of macro-aggregates and meso-aggregates decreased, while those of micro-aggregates increased.

As the decrease of soil aggregate size decreasing, the soil $\mathrm{C}_{\text {org }}$ and nutrients stocks of stand $\mathrm{A}$ and $\mathrm{B}$ decreased, and the soil $\mathrm{C}_{\text {org }}$ and nutrients stocks of stand $\mathrm{C}$ increased. Besides, the results showed that the stocks of $\mathrm{C}_{\text {org }}, \mathrm{N}_{\text {tot }}, \mathrm{P}_{\text {ava, }}$, exchangeable bases (including $\mathrm{Na}^{+}, \mathrm{Ca}^{2+}, \mathrm{Mg}^{2+}$ cations) in stand $\mathrm{A}$ and $\mathrm{B}$ noticeably 
reached over those in stand $\mathrm{C}$, and the reason was the loose soil structure of mixed stands had stronger ability to hold $\mathrm{C}_{\text {org }}$ and nutrients. Moreover, only the exchangeable $\mathrm{K}^{+}$stock of the pure stand (stand $\mathrm{C}$ ) was more dominant than that of the other two stands (stand A and B). That's because Cunninghamia lanceolata has the characteristics of fast-growing, needs to absorb a lot of nutrients and water from the soil for its own growth, so soil organic matter decomposition can be improved, but it is not conducive to the stocks of $\mathrm{C}_{\text {org }}$ and nutrients in the soil. Due to a small amount of litter, soil nutrients income is far less than the expenditure. With the large soil capacity, it is not conducive to the accumulation of soil nutrients. However, the spatial structure, root distribution and litter of mixed forests were better than those of pure stand, which increased the activity of soil animals and micro-organisms, and improved nutrient cycling and utilization rate (Niu et al., 2009), promoting the forming process of soil macro-aggregates. Moreover, the pattern mixing coniferous and broadleaved species increased the stock of soil $\mathrm{C}_{\text {org }}$ and nutrients. For, the second hypothesis here is evidenced.

\section{Conclusions}

Compared to the Cunninghamia lanceolata pure stand(C), the soil structure of mixed stands of Cunninghamia lanceolata with Michelia macclurei(A) and Mytilaria laosensis(B) was more stable. Due to the larger amount of litter, the soil structure of stand $A$ was better and stable than stand B. Soil $\mathrm{C}_{\text {org }}, \mathrm{N}_{\text {tot }}$ and $\mathrm{P}_{\text {ava }}$ contents of soil aggregates in different stand types increased with decreasing aggregate sizes, while the exchange base cation (including $\mathrm{Ca}^{2+}, \mathrm{Mg}^{2+}, \mathrm{K}^{+}, \mathrm{Na}^{+}$) contents mostly were decreased first and then increased among the three stands. However, only the exchangeable $\mathrm{K}^{+}$cation stock of the pure stand dominated among the organic and nutrients stocks, in addition, the rest of the other nutrients stocks of the mixed forests (stand A and B) took an advantage over the pure stand, especially stand $A$. Therefore, the mentioned two mixed pattern in this study can improve the soil $\mathrm{C}_{\text {org }}$ and nutrients stocks but reduce the exchangeable $\mathrm{K}^{+}$cation stock in different aggregate sizes of the pure stand, especially the mixed pattern of stand A. Selecting suitable broadleaf tree species mixed with Cunninghamia lanceolata can alleviate the problems of pure stand soil aggregate stability reduction and soil $\mathrm{C}_{\text {org }}$ and nutrient loss, so as to promote soil resources to be sustainably exploited and ensure soil health and quality in southern Guangxi of China.

\section{Abbreviations}

$\mathrm{C}_{\text {org }}$ : organic carbon; $\mathrm{N}_{\text {tot }}$ : total nitrogen; $\mathrm{P}_{\text {ava }}$ : available phosphorus; $\mathrm{K}^{+}$: exchangeable potassium; $\mathrm{Na}^{+}$: exchangeable sodium; $\mathrm{Ca}^{2+}$ : exchangeable calcium; $\mathrm{Mg}^{2+}$ : exchangeable magnesium

\section{Declarations}

\section{Acknowledgments}

The authors would like to express their gratitude to the editor and innominate referees for giving conducive advises and optimizing this article.

\section{Authors' contributions}


$S$ Ye conceived and designed the experiments. Y Huang and S Wang performed the experiments, analysed the data, and wrote the manuscript. The authors read and approved the final manuscript.

\section{Funding}

This work was funded by the National Natural Science Foundation of China (No. 31460196).

\section{Availability of data and materials}

Not applicable.

\section{Ethics approval and consent to participate}

Not applicable.

\section{Consent for publication}

Not applicable.

\section{Competing interests}

The authors declare they have no competing interests.

\section{Author details}

Forestry College, Guangxi University, Nanning, 530004, China

\section{References}

Almajmale A, Hardie M, Doyle R, et al. Influence of soil properties on the aggregate stability of cultivated sandy clay loams. Journal of Soil and Sediments, 2017, 17, 800-809.

Adesodun J K, Adeyemi E F, Oyegoke C O. Distribution of nutrient elements within water-stable aggregates of two tropical agro-ecological soils under different land uses. Soil \& Tillage Research, 2006, 92, 190-197.

Ayoubi S, Karchegani P M, Mosaddeghi M R, et al. Soil aggregation and organic carbon as affected by topography and land use change in western Iran. Soil \& Tillage Research, 2012, 121, 18-26.

Alagöz Z, Yilmaz E. Effects of different sources of organic matter on soil aggregate formation and stability: A laboratory study on a Lithic Rhodoxeralf from Turkey. Soil and Tillage Research, 2009, 103, 419-424. 
Cheng H, Gong Y B, Fu Y X, et al. Soil Aggregate Stability and Characteristics of Organic Carbon Components in Three Forests of the Southwest Edge of Sichuan Basin. Journal of Soil and Water Conservation, 2018, 32, 109-115.

Castellano M J, Mueller K E, Olk D C, et al. Integrating plant litter quality, soil organic matter stabilization, and the carbon saturation concept. Global change biology, 2015, 21: 3200-3209.

Egan G, Crawley M J, Fornara D A. Effects of long-term grassland management on the carbon and nitrogen pools of different soil aggregate fractions. Science of the Total Environment, 2018, 614, 810-819.

Fattet M, Fu Y, Ghestem M, et al. Effects of vegetation type on soil resistance to erosion: relationship between aggregate stability and shear strength. Catena, 2011, 87, 60-69.

Ferro N D, Berti A, Francioso O, et al. Investigating the effects of wettability and pore size distribution on aggregate stability: the role of soil organic matter and the humic fraction. European Journal of Soil Science, 2012, 63, 152-164.

Ge N, Wei X, Wang X, et al. Soil texture determines the distribution of aggregate-associated carbon, nitrogen and phosphorous under two contrasting land use types in the Loess Plateau. Catena, 2019, 172, 148-157.

Guan F Y, Tang X L, Fan S H, et al. Changes in soil carbon and nitrogen stocks followed the conversion from secondary forest to Chinese fir and Moso bamboo plantations. Catena, 2015, 133:455-460.

Jiang X, Hu Y, Bedell J H, et al. Soil organic carbon and nutrient content in aggregate-size fractions of a subtropical rice soil under variable tillage. Soil Use and Management, 2011, 27, 28-35.

Kemper W D, Chepil W S. Size distribution of aggregation. In: Black, C.A., et al. (Eds.). Part 1. American Society of Agronomy. Monograph, 1965, pp: 499-510.

Li C, Li Y, Xie J, et al. Accumulation of organic carbon and its association with macro-aggregates during 100 years of oasis formation. Catena, 2019, 172, 770-780.

Liao X Z. Effect of clear cutting clearances on soil physicochemical properties of Cunninghamia lanceolata stand. Protection Forest Science and Technology. 2015, 10: 7-8.

Lu Y M, Wu D M, Xu E L, et al. Effects of Chinese Fir Inter planting with Broad-leaved Trees on Soil Phosphorus Fractions . Journal of Soil and Water Conservation, 2020, 34, 275-282.

Ma R, Cai C, Li Z, et al. Evaluation of soil aggregate microstructure and stability under wetting and drying cycles in two Ultisols using synchrotron-based X-ray micro-computed tomography. Soil \& Tillage Research, $2015,149,1-11$.

Mangalassery S, Sjogersten S, Sparkes D L, et al. The effect of soil aggregate size on pore structure and its consequence on emission of greenhouse gases. Soil and Tillage Research, 2013, 132, 39-46. 
Niu D, Wang S L, Ouyang Z Y. Comparisons of carbon storages in Cunninghamia lanceolata and Michelia macclurei plantations during a 22-year period in southern China. Journal of Environmental Sciences, 2009, 21, 801-805.

Ranatunga T D, Reddy S S, Taylor R W. Phosphorus distribution in soil aggregate size fractions in a poultry litter applied soil and potential environmental impacts. Geoderma, 2013, 192, 446-452.

Ostrowska A, Porebska $\mathrm{G}$. Assessment of the $\mathrm{C} / \mathrm{N}$ ratio as an indicator of the decomposability of organic matter in forest soils . Ecological Indicators, 2015, 49, 104-109.

Six J, Paustian K. Aggregate-associated soil organic matter as an ecosystem property and a measurement tool. Soil Biology and Biochemistry, 2012, 68, 4-9

Sarker J R, Singh B P, Cowie A L, et al. Agricultural management practices impacted carbon and nutrient concentrations in soil aggregates, with minimal influence on aggregate stability and total carbon and nutrient stocks in contrasting soils. Soil \& Tillage Research, 2018, 178, 209-223.

Wen J, Wang X L, Wang Y L, et al. Distribution Characteristics and Mechanism Discussion of Soil Cation Exchange Capacity and Exchangeable Based Cations of Alpine Grassland in the Source Region of Yangtze River. Ecology and Environmental Sciences, 2019, 28, 488-497.

Wang F H, Lü S, Huang R, et al. Distribution of Organic Carbon in Soil Aggregates from Four Kinds of Forest Vegetation on Jinyun Mountain . Environmental Science, 2019, 40: 1504-1511.

Wang Q K, Wang S L, Huang Y. Comparisons of litterfall, litter decomposition and nutrient return in a monoculture Cunninghamia lanceolata and a mixed stand in southern China, Forest Ecology and Management, 2008, 225: 1210-1218.

Wang S L, Liao L P, Deng S J, et al. Mixed of Cunninghamia lanceolata with Michelia macclurei and restoration of self-sustaining mechanism in G. lanceolate Plantation . Chinese Journal of Applied Ecology, 2000, 11(01): 34-37.

Wang S Q, Zhang Z, Ye S M. Response of soil fertility characteristics in water-stable aggregates to tea cultivation age in hilly region of southern Guangxi, China. Catena, 2020a, 191, 1-11.

Wang W B, Zhang Q, Sun X M, et al. Effects of mixed-species litter on bacterial and fungal lignocellulose degradation functions during litter decomposition. Soil Biology and Biochemistry, 2020b, 141.

Wiesmeier M, Steffens M, Mueller CW, et al. Aggregate stability and physical protection of soil organic carbon in semi-arid steppe soils. European Journal of Soil Science, 2012, 63, 22-31.

Wu W, Zheng Z, Li T, et al. Distribution of inorganic phosphorus fractions in water-stable aggregates of soil from tea plantations converted from farmland in the hilly region of western Sichuan, China . Journal of Soils and Sediments, 2018, 18: 906-916. 
Yin $\mathrm{H}$ J, Wheeler E, Phillips R P. Root-induced changes in nutrient cycling in forests depend on exudation rates. Soil Biology and Biochemistry, 2014, 78:213-221.

Zou C, Li Y, Huang W, et al. Rotation and manure amendment increase soilmacro-aggregates and associated carbon and nitrogen stocks in flue-cured tobaccoproduction. Geoderma, 2018, 325, 49-58.

Zhao D, Xu M X, Liu G B, et al. Quantification of soil aggregate microstructure on abandoned cropland during vegetative succession using synchrotron radiation-based micro-computed tomography. Soil and Tillage Research, 2017, 165, 239-246

Zhou Y, Boutton T W, Wu X. Soil C: N: P stoichiometry responds to vegetation change from grassland to woodland. Biogeochemistry, 2018, 140, 341-357.

Zhang Y, Tigabu M, Zhang Y., et al. Soil parent material and stand development stage effects on labile soil C and N pools in Chinese fir plantations. Geoderma, 2019, 338, 247-258.

\section{Tables}

Table 1 soil physicochemical properties in different stand types 


\begin{tabular}{|c|c|c|c|c|c|c|}
\hline \multirow[t]{2}{*}{ Item } & \multicolumn{3}{|l|}{$0-10 \mathrm{~cm}$} & \multicolumn{3}{|l|}{$10-20 \mathrm{~cm}$} \\
\hline & Stand A & Stand B & Stand C & Stand A & Stand B & Stand C \\
\hline $\begin{array}{l}\text { Bulk density } \\
\left(\mathrm{g} \mathrm{cm}^{-3}\right)\end{array}$ & $\begin{array}{l}1.24 \pm 0.01 \\
b\end{array}$ & $\begin{array}{l}1.26 \pm 0.02 \\
b\end{array}$ & $\begin{array}{l}1.31 \pm 0.02 \\
a\end{array}$ & $\begin{array}{l}1.26 \pm 0.01 \\
b\end{array}$ & $\begin{array}{l}1.27 \pm 0.01 \\
b\end{array}$ & $\begin{array}{l}1.33 \pm 0.02 \\
a\end{array}$ \\
\hline $\begin{array}{l}\text { Organic C (g } \\
\left.\mathrm{kg}^{-1}\right)\end{array}$ & $\begin{array}{l}15.2 \pm 0.24 \\
\mathrm{a}\end{array}$ & $\begin{array}{l}13.8 \pm 0.36 \\
b\end{array}$ & $\begin{array}{l}10.1 \pm 0.26 \\
c\end{array}$ & $\begin{array}{l}13.07 \pm 0.21 \\
\text { a }\end{array}$ & $\begin{array}{l}9.97 \pm 0.12 \\
b\end{array}$ & $\begin{array}{l}9.44 \pm 0.23 \\
c\end{array}$ \\
\hline $\begin{array}{l}\text { Total } \mathrm{N}\left(\mathrm{g} \mathrm{kg}^{-}\right. \\
\left.{ }^{1}\right)\end{array}$ & $\begin{array}{l}1.16 \pm 0.05 \\
a\end{array}$ & $\begin{array}{l}1.02 \pm 0.07 \\
b\end{array}$ & $\begin{array}{l}0.75 \pm 0.01 \\
\mathrm{c}\end{array}$ & $\begin{array}{l}0.92 \pm 0.08 \\
a\end{array}$ & $\begin{array}{l}0.82 \pm 0.02 \\
b\end{array}$ & $\begin{array}{l}0.91 \pm 0.06 \\
a\end{array}$ \\
\hline $\mathrm{C} / \mathrm{N}$ ratio & $13.2 \pm 0.6 \mathrm{a}$ & $\begin{array}{l}13.61 \pm 0.66 \\
\text { a }\end{array}$ & $13.6 \pm 0.4 a$ & $\begin{array}{l}14.46 \pm 1.50 \\
a\end{array}$ & $\begin{array}{l}12.29 \pm 0.35 \\
\text { b }\end{array}$ & $\begin{array}{l}10.42 \pm 0.70 \\
c\end{array}$ \\
\hline $\begin{array}{l}\text { Available } P \\
\left(\mathrm{mg} \mathrm{kg}^{-1}\right)\end{array}$ & $\begin{array}{l}6.81 \pm 0.38 \\
a\end{array}$ & $\begin{array}{l}5.81 \pm 0.61 \\
b\end{array}$ & $\begin{array}{l}4.05 \pm 0.35 \\
c\end{array}$ & $\begin{array}{l}2.67 \pm 0.42 \\
a\end{array}$ & $\begin{array}{l}1.29 \pm 0.20 \\
C\end{array}$ & $\begin{array}{l}2.27 \pm 0.12 \\
b\end{array}$ \\
\hline $\begin{array}{l}\text { Total EB } \\
\left(\mathrm{cmol} \mathrm{kg}^{-1}\right)\end{array}$ & $\begin{array}{l}6.13 \pm 0.16 \\
a\end{array}$ & $\begin{array}{l}6.04 \pm 0.16 \\
a\end{array}$ & $\begin{array}{l}6.16 \pm 0.18 \\
a\end{array}$ & $\begin{array}{l}5.74 \pm 0.10 \\
a\end{array}$ & $\begin{array}{l}5.37 \pm 0.11 \\
\text { b }\end{array}$ & $\begin{array}{l}5.81 \pm 0.26 \\
a\end{array}$ \\
\hline $\begin{array}{l}\text { Exchangeable } \\
\mathrm{Ca}^{2+}(\mathrm{cmol} \mathrm{kg} \\
\left.{ }^{1}\right)\end{array}$ & $\begin{array}{l}5.38 \pm 0.18 \\
a\end{array}$ & $\begin{array}{l}5.43 \pm 0.15 \\
a\end{array}$ & $\begin{array}{l}5.38 \pm 0.13 \\
a\end{array}$ & $\begin{array}{l}5.18 \pm 0.09 \\
a\end{array}$ & $\begin{array}{l}4.97 \pm 0.06 \\
b\end{array}$ & $\begin{array}{l}5.29 \pm 0.20 \\
a\end{array}$ \\
\hline $\begin{array}{l}\text { Exchangeable } \\
\mathrm{Mg}^{2+}(\mathrm{cmol} \\
\left.\mathrm{kg}^{-1}\right)\end{array}$ & $\begin{array}{l}0.46 \pm 0.01 \\
a\end{array}$ & $\begin{array}{l}0.41 \pm 0.01 \\
a\end{array}$ & $\begin{array}{l}0.46 \pm 0.06 \\
a\end{array}$ & $0.4 \pm 0.02 \mathrm{a}$ & $\begin{array}{l}0.24 \pm 0.08 \\
b\end{array}$ & $\begin{array}{l}0.13 \pm 0.01 \\
c\end{array}$ \\
\hline $\begin{array}{l}\text { Exchangeable } \\
\mathrm{K}^{+}\left(\mathrm{cmol} \mathrm{kg}^{-1}\right)\end{array}$ & $\begin{array}{l}0.15 \pm 0.01 \\
b\end{array}$ & $\begin{array}{l}0.08 \pm 0.01 \\
c\end{array}$ & $\begin{array}{l}0.24 \pm 0.03 \\
a\end{array}$ & $\begin{array}{l}0.12 \pm 0.01 \\
b\end{array}$ & $\begin{array}{l}0.11 \pm 0.01 \\
b\end{array}$ & $\begin{array}{l}0.33 \pm 0.08 \\
a\end{array}$ \\
\hline $\begin{array}{l}\text { Exchangeable } \\
\mathrm{Na}^{+}(\mathrm{cmol} \mathrm{kg} \\
\left.{ }^{1}\right)\end{array}$ & $\begin{array}{l}0.14 \pm 0.01 \\
a\end{array}$ & $\begin{array}{l}0.12 \pm 0.01 \\
b\end{array}$ & $\begin{array}{l}0.08 \pm 0.01 \\
C\end{array}$ & $\begin{array}{l}0.04 \pm 0.00 \\
b\end{array}$ & $\begin{array}{l}0.05 \pm 0.00 \\
a\end{array}$ & $\begin{array}{l}0.06 \pm 0.01 \\
a\end{array}$ \\
\hline $\mathrm{R}_{\mathrm{dm}}$ & $\begin{array}{l}20.12 \pm 1.80 \\
b\end{array}$ & $\begin{array}{l}29.49 \pm 2.09 \\
\text { a }\end{array}$ & $\begin{array}{l}17.99 \pm 0.72 \\
b\end{array}$ & $\begin{array}{l}34.05 \pm 1.81 \\
\text { a }\end{array}$ & $\begin{array}{l}32.19 \pm 2.77 \\
\text { a }\end{array}$ & $\begin{array}{l}14.86 \pm 2.88 \\
b\end{array}$ \\
\hline
\end{tabular}

Note: Data represent the average of five replicates \pm standard deviations. Different lower case letters indicate significant differences $(P<0.05)$ among the different stand types. Total EB: total exchangeable bases; $R_{d m}$ : the ratio of divalent cations (exchangeable $\mathrm{Ca}^{2+}$ and $\mathrm{Mg}^{2+}$ ) to monovalent cations (exchangeable $\mathrm{K}^{+}$and $\mathrm{Na}^{+}$).

Table 2 Content and stability of soil aggregates as affected by different stand types 


\begin{tabular}{|c|c|c|c|c|c|c|c|c|}
\hline \multirow{2}{*}{$\begin{array}{l}\text { Soil } \\
\text { thickness }\end{array}$} & \multirow{2}{*}{$\begin{array}{l}\text { Stand } \\
\text { type }\end{array}$} & \multirow[t]{2}{*}{$\mathrm{MWD}(\mathrm{mm})$} & \multicolumn{3}{|c|}{ Composition of soil aggregate fractions (\%) } & \multicolumn{3}{|c|}{ Effects } \\
\hline & & & $>2 \mathrm{~mm}$ & $2-0.25 \mathrm{~mm}$ & $<0.25 \mathrm{~mm}$ & S & A & S \\
\hline \multirow[t]{3}{*}{$0-10 \mathrm{~cm}$} & Stand A & $\begin{array}{l}2.21 \pm 0.10 \\
\mathrm{a}\end{array}$ & $\begin{array}{l}51.90 \pm 3.00 \\
\text { Aa }\end{array}$ & $\begin{array}{l}33.30 \pm 4.40 \\
\mathrm{Ba}\end{array}$ & $\begin{array}{l}14.80 \pm 4.50 \\
\text { Cc }\end{array}$ & ns & ** & ** \\
\hline & Stand B & $\begin{array}{l}1.96 \pm 0.13 \\
b\end{array}$ & $\begin{array}{l}45.00 \pm 3.90 \\
A b\end{array}$ & $\begin{array}{l}31.20 \pm 3.40 \\
\mathrm{Ba}\end{array}$ & $\begin{array}{l}23.80 \pm 4.20 \\
\mathrm{Cb}\end{array}$ & & & \\
\hline & Stand C & $\begin{array}{l}1.54 \pm 0.12 \\
c\end{array}$ & $\begin{array}{l}32.40 \pm 3.00 \\
\mathrm{Bc}\end{array}$ & $\begin{array}{l}31.80 \pm 1.20 \\
\mathrm{Ca}\end{array}$ & $\begin{array}{l}35.80 \pm 5.00 \\
\mathrm{Aa}\end{array}$ & & & \\
\hline \multirow[t]{3}{*}{$10-20 \mathrm{~cm}$} & Stand A & $\begin{array}{l}2.10 \pm 0.07 \\
a\end{array}$ & $\begin{array}{l}49.20 \pm 1.40 \\
\mathrm{Aa}\end{array}$ & $\begin{array}{l}31.50 \pm 3.40 \\
\mathrm{Ba}\end{array}$ & $\begin{array}{l}19.30 \pm 4.30 \\
\text { Cc }\end{array}$ & ns & ** & ** \\
\hline & Stand B & $\begin{array}{l}1.52 \pm 0.09 \\
b\end{array}$ & $\begin{array}{l}33.10 \pm 2.70 \\
\mathrm{Bb}\end{array}$ & $\begin{array}{l}27.90 \pm 1.90 \\
\text { Cab }\end{array}$ & $\begin{array}{l}39.00 \pm 2.80 \\
A b\end{array}$ & & & \\
\hline & Stand C & $1.38 \pm 0.12 \mathrm{c}$ & $\begin{array}{l}29.70 \pm 3.50 \\
\mathrm{Bb}\end{array}$ & $\begin{array}{l}24.80 \pm 2.90 \\
\mathrm{Bb}\end{array}$ & $\begin{array}{l}45.50 \pm 4.30 \\
\mathrm{Aa}\end{array}$ & & & \\
\hline
\end{tabular}

Note: Different upper case letters in each row indicate significant differences $(P<0.05)$ among the different soil aggregate fractions. Different lower case letters in each column indicate significant differences $(P<0.05)$ among the different stand types. S: stand types; A: aggregate sizes.

Table 3 Effects of stand type, aggregate size, and their interactions on the soil aggregate-relevant $\mathrm{OC}$ and nutrients 


\begin{tabular}{|c|c|c|c|c|c|c|}
\hline \multirow[t]{3}{*}{ Item } & \multicolumn{6}{|c|}{ Effects } \\
\hline & \multicolumn{3}{|c|}{$0-10 \mathrm{~cm}$} & \multicolumn{3}{|c|}{$10-20 \mathrm{~cm}$} \\
\hline & $S$ & $A$ & SXA & S & $A$ & SXA \\
\hline Organic C $\left(\mathrm{g} \mathrm{kg}^{-1}\right)$ & $\star \star$ & ** & ** & $\star \star$ & ** & ** \\
\hline Total N (g kg-1) & $\star \star$ & ns & ** & ** & ** & ** \\
\hline $\mathrm{C} / \mathrm{N}$ ratio & ns & ** & ** & $\star \star$ & ns & ** \\
\hline Available P (mg kg-1) & $\star \star$ & ** & ** & $\star \star$ & ** & $\star \star$ \\
\hline Total EB (cmol kg-1) & ns & ns & ns & ** & ns & ns \\
\hline Exchangeable $\mathrm{Ca}^{2+}\left(\mathrm{cmol} \mathrm{kg}^{-1}\right)$ & ns & ns & ns & $\star \star$ & ns & ns \\
\hline Exchangeable $\mathrm{Mg}^{2+}\left(\mathrm{cmol} \mathrm{kg}^{-1}\right)$ & * & ns & ns & ** & ns & ns \\
\hline Exchangeable $\mathrm{K}^{+}\left(\mathrm{cmol} \mathrm{kg}^{-1}\right)$ & 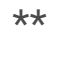 & 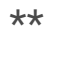 & ** & ** & ns & ns \\
\hline Exchangeable $\mathrm{Na}^{+}\left(\mathrm{cmol} \mathrm{kg}^{-1}\right)$ & ** & ** & ns & ** & ** & ns \\
\hline Rdm & $\star \star$ & ** & ns & $\star \star$ & $\star \star$ & ns \\
\hline
\end{tabular}

Note: S: stand type; A: aggregate size. ${ }^{*}{ }^{*}{ }^{*}$ and ns indicate significant at $P<0.01, P<0.05$, and $P>0.05$, respectively.

Table 4 Effects of stand type, aggregate size, and their interactions on the soil aggregate-relevant OC and nutrients storages 


\begin{tabular}{|c|c|c|c|c|c|c|}
\hline \multirow[t]{3}{*}{ Storage } & \multicolumn{6}{|c|}{ Effects } \\
\hline & \multicolumn{3}{|c|}{$0-10 \mathrm{~cm}$} & \multicolumn{3}{|c|}{$10-20 \mathrm{~cm}$} \\
\hline & $\mathrm{S}$ & $A$ & SXA & $\mathrm{S}$ & $A$ & SXA \\
\hline Organic C $\left(\mathrm{g} \mathrm{kg}^{-1}\right)$ & ** & ** & ** & ** & ** & ** \\
\hline Total N ( $\left.\mathrm{g} \mathrm{kg}^{-1}\right)$ & ** & ** & ** & ** & ** & ** \\
\hline $\mathrm{C} / \mathrm{N}$ rate & ns & ** & $\star \star$ & ** & ** & ** \\
\hline Available $\mathrm{P}\left(\mathrm{mg} \mathrm{kg}^{-1}\right)$ & ** & ** & $\star \star$ & ** & * & ** \\
\hline Total EB (cmol kg-1) & ns & ** & ** & * & ** & ** \\
\hline Exchangeable $\mathrm{Ca}^{2+}\left(\mathrm{cmol} \mathrm{kg}^{-1}\right)$ & ns & ** & ** & * & ** & ** \\
\hline Exchangeable $\mathrm{Mg}^{2+}\left(\mathrm{cmol} \mathrm{kg}^{-1}\right)$ & ns & ** & ** & ** & ** & ** \\
\hline Exchangeable $\mathrm{K}^{+}\left(\mathrm{cmol} \mathrm{kg}^{-1}\right)$ & ** & ** & ** & ** & * & $\star *$ \\
\hline Exchangeable $\mathrm{Na}^{+}\left(\mathrm{cmol} \mathrm{kg}^{-1}\right)$ & $\star *$ & $\star \star$ & $\star *$ & $\star \star$ & $\star \star$ & $\star *$ \\
\hline
\end{tabular}

Note: S: stand type; A: aggregate size. ${ }^{*},{ }^{*}$ and $n$ s indicate significant at $P<0.01, P<0.05$, and $P>0.05$, respectively.

\section{Figures}




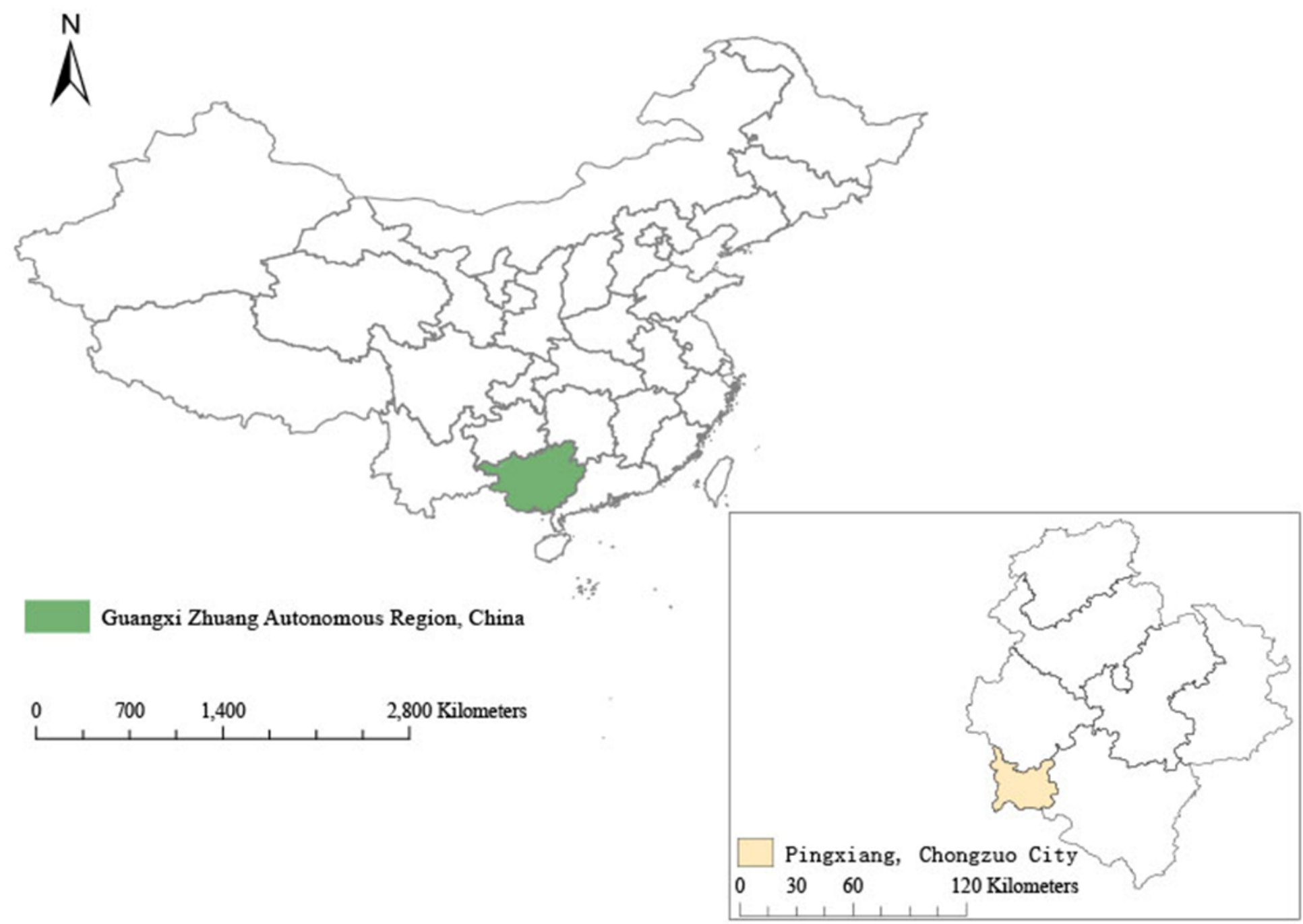

Figure 1

Location of the experimental site. Note: The designations employed and the presentation of the material on this map do not imply the expression of any opinion whatsoever on the part of Research Square concerning the legal status of any country, territory, city or area or of its authorities, or concerning the delimitation of its frontiers or boundaries. This map has been provided by the authors. 

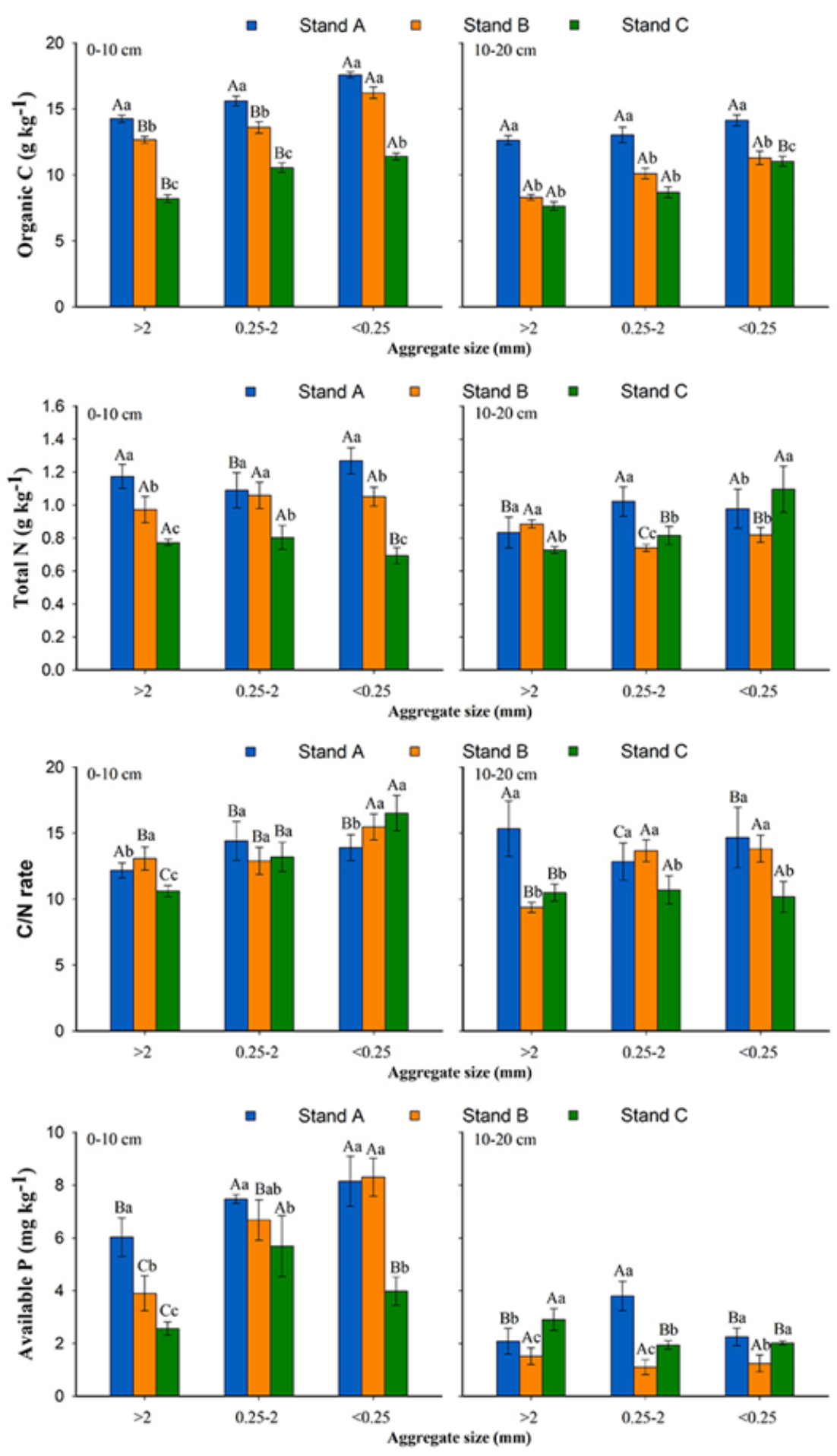

Figure 2

Soil aggregate-associated organic carbon and nutrient concentrations as affected by different stand types. Data represent the average of five replicates and error bars represent standard deviations. 

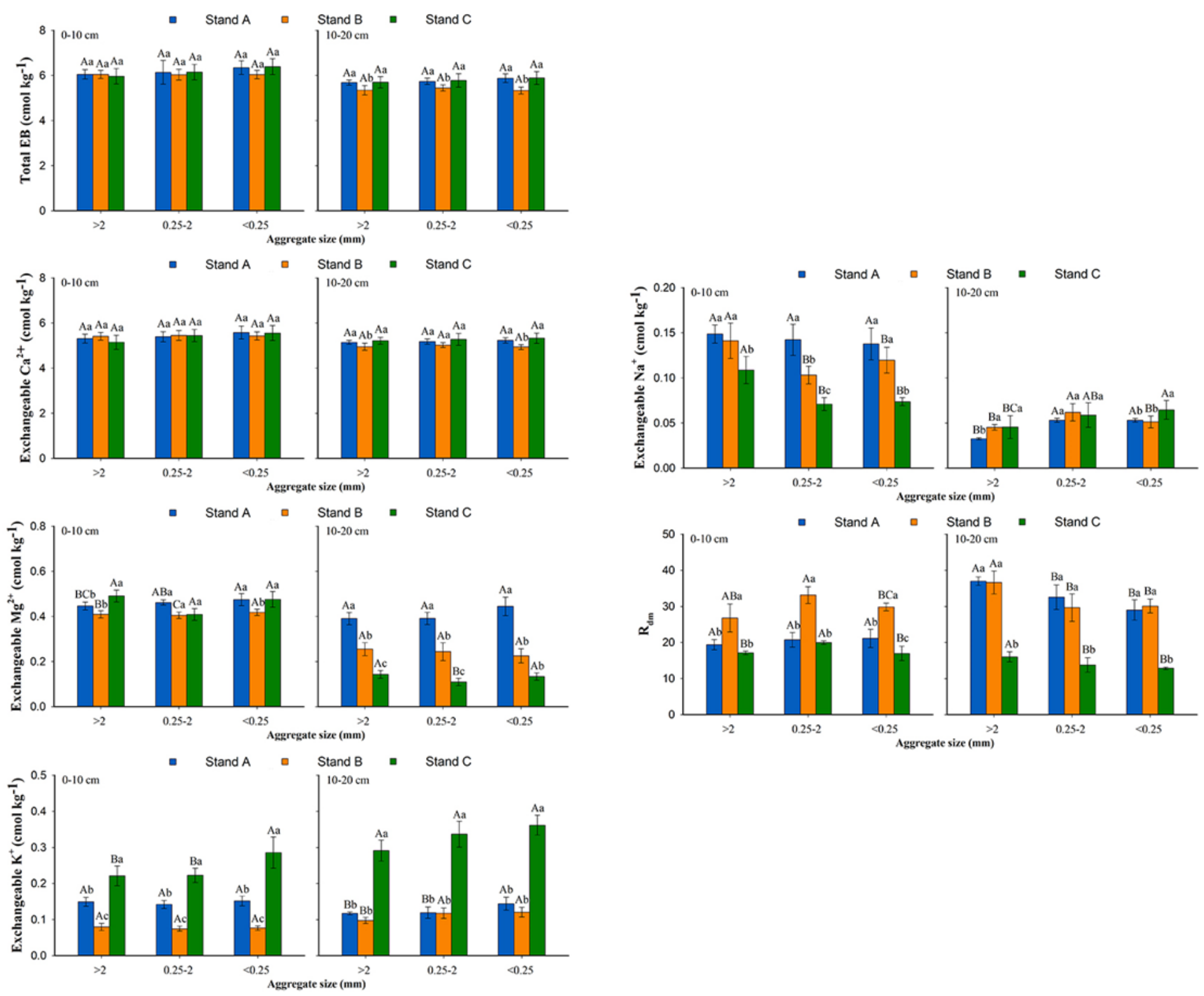

\section{Figure 3}

Soil aggregate-associated exchangeable base contents as affected by different stand types. Data represent the average of five replicates and error bars represent standard deviations. 

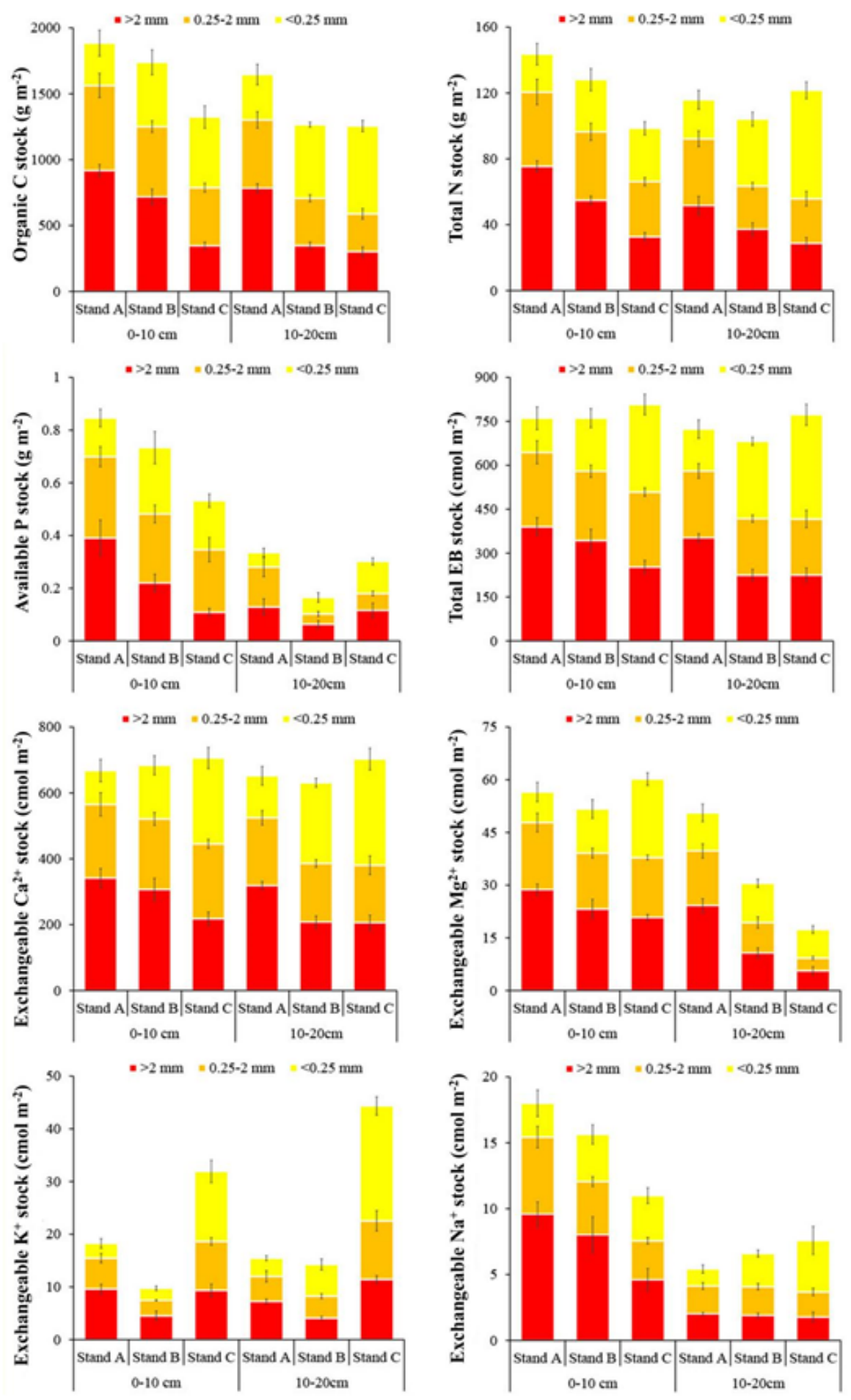

Figure 4

Soil aggregate relevant Corg and nutrient stocks as affected by different stand types. Data represent the average of five replicates and error bars represent standard deviations. 

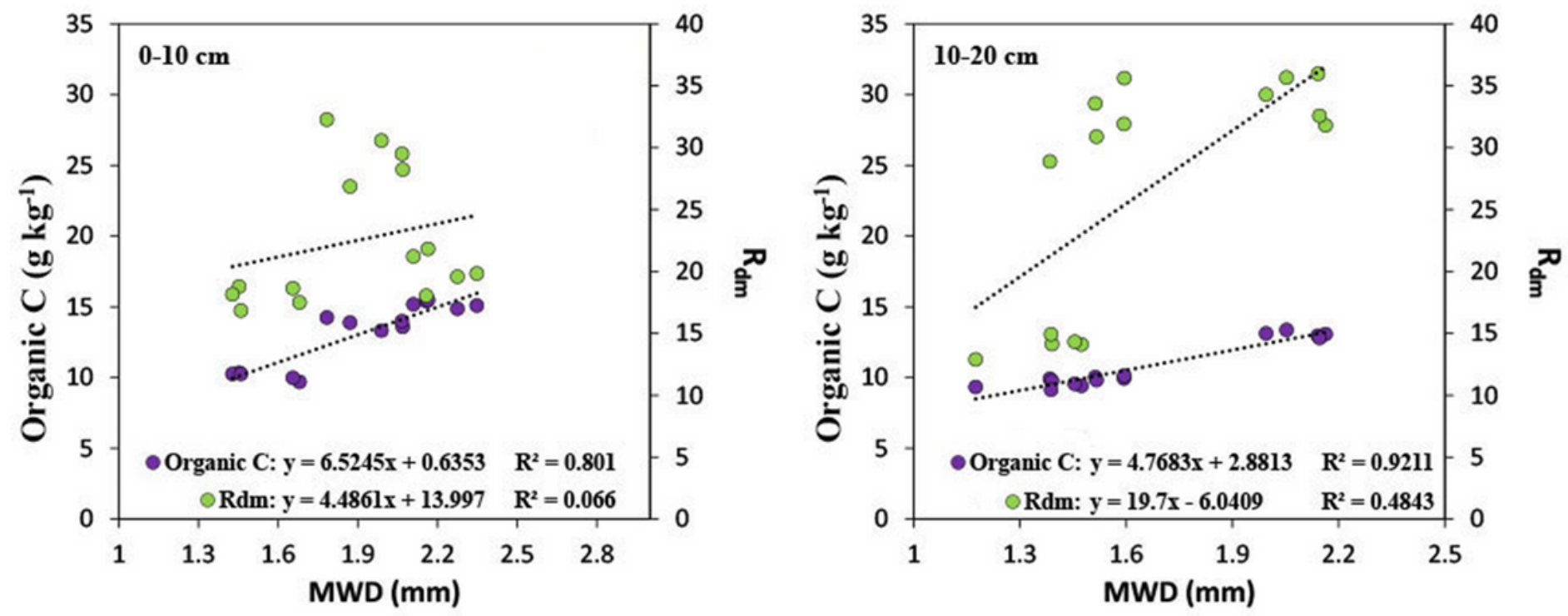

\section{Figure 5}

Relationships of soil aggregate stability (MWD) with the organic carbon content and Rdm rate of different stand types in each layer. 